University of Nebraska - Lincoln

DigitalCommons@University of Nebraska - Lincoln

Nebraska Cooperative Fish \& Wildlife Research Nebraska Cooperative Fish \& Wildlife Research Unit -- Staff Publications

2007

\title{
Intraspecific resource partitioning by an opportunistic strategist, inland silverside Menidia beryllina
}

Christopher J. Chizinski

Texas Tech University, cchizinski2@unl.edu

C. G. Huber

Texas Tech University

M. Longoria

Texas Tech University

Kevin L. Pope

University of Nebraska-Lincoln, kpope2@unl.edu

Follow this and additional works at: https://digitalcommons.unl.edu/ncfwrustaff

Part of the Other Environmental Sciences Commons

Chizinski, Christopher J.; Huber, C. G.; Longoria, M.; and Pope, Kevin L., "Intraspecific resource partitioning by an opportunistic strategist, inland silverside Menidia beryllina" (2007). Nebraska Cooperative Fish \& Wildlife Research Unit -- Staff Publications. 10.

https://digitalcommons.unl.edu/ncfwrustaff/10

This Article is brought to you for free and open access by the Nebraska Cooperative Fish \& Wildlife Research Unit at DigitalCommons@University of Nebraska - Lincoln. It has been accepted for inclusion in Nebraska Cooperative Fish \& Wildlife Research Unit -- Staff Publications by an authorized administrator of DigitalCommons@University of Nebraska - Lincoln. 


\title{
Intraspecific resource partitioning by an opportunistic strategist, inland silverside Menidia beryllina
}

\author{
By C. J. Chizinski, C. G. Huber, M. Longoria and K. L. Pope \\ Wildlife and Fisheries Management Institute, Texas Tech University, Lubbock, TX, USA
}

\begin{abstract}
Summary
Seasonal variation in prey consumption and food resource overlap was evident in an inland water body for mature male, mature female and immature inland silverside (Menidia beryllina). During the first growth phase marked by intensive somatic growth by immature inland silverside, few adults were present in the population ( $28 \%$ of total catch), thus minimizing intraspecific competition for food resources between juvenile and adult inland silverside. During the second growth phase by adults, few juvenile inland silverside were present $(0 \%$ of total catch) in the population, again minimizing intraspecific competition for food resources between juvenile and adult inland silverside. A divergence in food resource overlap was observed when mature male, mature female and immature inland silverside were present in the population. These population-level demographic responses to energy acquisition are likely necessary to maximize individual growth of mature male, mature female and immature inland silverside.
\end{abstract}

\section{Introduction}

Inland silverside (Menidia beryllina) is a euryhaline, zooplanktivorous, annual fish species common throughout the USA and inhabiting reservoirs, large rivers and coastal estuaries. Inland silverside have two periods of rapid growth within their short life span (Huber and Bengtson, 1999). The first growth period occurs during the juvenile stage prior to the onset of winter, where the fish accomplishes approximately $27 \%$ of its total growth. Little to no growth occurs during winter. The second growth phase generally in May to June occurs when inland silverside accomplishes the remaining $73 \%$ of its total growth (Huber and Bengtson, 1999). During the second growth phase, a separation of energetic demands between male and female inland silverside occurs. For example, female body and gonad weights generally are $10 \%$ and $441 \%$, respectively, greater than males (Huber and Bengtson, 1999). In addition, male inland silverside gonadosomatic index (GSI) decreases whereas female inland silverside GSI increases during the growing season (Huber and Bengtson, 1999). The increase in energy allocation during the reproductive season allows the female inland silverside to be a prolific breeder capable of producing 30000 eggs a month (Stoeckel, 1984). The simultaneous somatic and gonadal growth during the second growth phase by inland silverside undoubtedly requires the ingestion of a massive amount of prey to meet energetic demands, and thus creates potential for detrimental intraspecific competition.

Given the overlapping energy demands, inland silverside would likely face intense intraspecific competition for food resources unless there is differentiation in food resources. For the purpose of this study, the focus was on intraspecific partitioning of food resources by inland silverside because $M$. beryllina is the main obligate planktivore in the inland water body studied. Other studies have focused on interspecific competition of inland silverside with its congener Atlantic silverside (Menidia menidia) (Bengtson, 1982, 1984, 1985). In order to meet the energy demand of the two coinciding growth periods (first stage juvenile growth and second stage adult growth), partitioning of food resources is expected so that suitable energy is available to meet demands of the mature male, mature female, and immature inland silverside. The objective of this study was to characterize the food habits and measure the degree of food-resource overlap between mature male, mature female, and immature inland silverside throughout the breeding and growing seasons in an inland water body.

\section{Materials and methods \\ Study area}

Buster Long Lake is a modified playa lake in Lubbock County, Texas, USA that is used primarily for storm-water management (Schramm et al., 1992). Buster Long Lake also provides a recreational fishing opportunity for Lubbock citizens. Although fishes originally were unable to colonize this ephemeral wetland, altered hydrology for storm-water management created a permanent lake that supports a viable fish community (Smith, 2003). Common fishes present in Buster Long Lake are bluegill (Lepomis macrochirus), common carp (Cyprinus carpio), inland silverside, and largemouth bass (Micropterus salmoides) (Shavlik, 2000).

\section{Sample collection and processing}

From May 15 to October 14, 2003, 25 inland silverside were collected weekly using a bag seine $(1.8 \times 9.1-\mathrm{m}$ and $5-\mathrm{mm}$ mesh) during 17.00-22.00 hours. Fish were immediately killed and kept on ice until they could be processed in the laboratory. In the laboratory, inland silverside weight (g), total length (TL; $\mathrm{mm}$ ), and gender (mature male, mature female or immature) were recorded. The entire gut was removed and preserved in $10 \%$ buffered formalin for processing at a later date.

The foregut was removed from the entire gut and blotted dry. The full foregut was weighed to obtain weight of the stomach and its contents. The stomach was cut open and prey items were washed out into a Petri dish. Cladocerans were identified to genus, Diptera to order and no distinction was made among copepods. After identification, prey were enumerated and measured at $10 \times$ magnification. The empty 


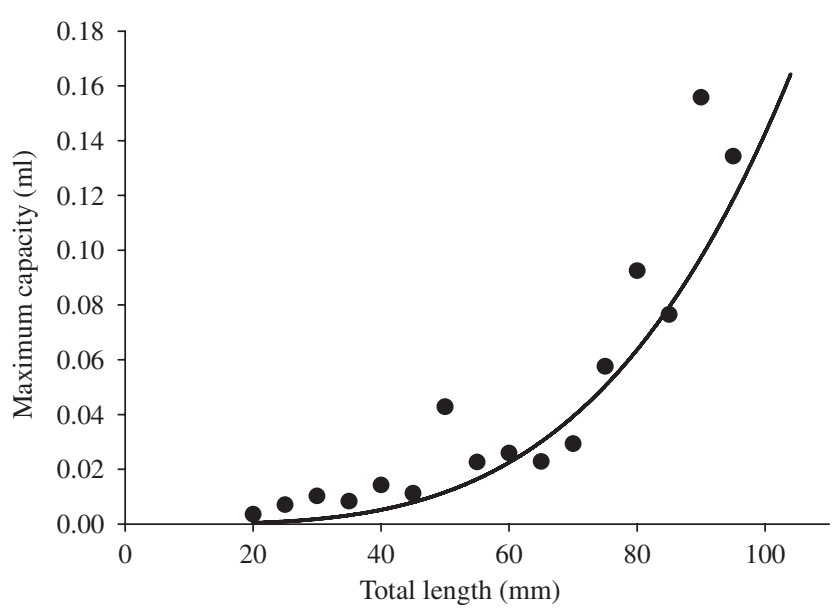

Fig. 1. Relationship $\left(r^{2}=0.88 ; \mathrm{n}=550\right)$ between maximum stomach capacity and total length of inland silverside (Menidia beryllina) in Buster Long Lake, Texas. A point represents maximum total volume of prey observed in an individual stomach plotted as midpoint for each 5-mm length group

stomach was blotted dry and reweighed to obtain a total mass of prey contents (by subtraction).

\section{Data analysis}

For analyses, sampled $M$. beryllina were divided into gender categories: mature male, mature female and immature for each month. Prey were categorized as copepods, Bosmina, Chydorus, Daphnia and Diptera. Data analysis was completed using Matlab version 7.1 and $\mathrm{R}$ version 2.1.1.

Stomach capacity, $C$, was calculated using techniques described by Knight and Margraf (1982). Food habit data from inland silverside were categorized into 5-mm length groups; length groups with a sample size $<5$ were eliminated. Maximum total mass of stomach contents was then plotted (Fig. 1) as a function of the midpoint of each length group and used to derive an exponential regression equation that related stomach capacity to TL (mm; Knight and Margraf, 1982). The length-specific stomach capacity $\left(C ; r^{2}=0.88 ; \mathrm{n}=550\right)$ was:

$C=8.36 \times 10^{-9} \cdot \mathrm{TL}^{3.62}$

Total prey mass was divided by $C$ to estimate stomach fullness for each individual; median values were used for each gender group. To determine if significant differences existed in stomach fullness between mature male, mature female, and immature inland silverside, a Kruskal-Wallis rank-sum test was applied to stomach fullness for each pair-wise combination. Feeding activity index was calculated as: $100\left(G_{\mathrm{F}} / G_{\mathrm{E}}\right)$, where $G_{\mathrm{F}}$ are the foreguts with food and $G_{\mathrm{E}}$ are foreguts with no food. Feeding activity index is a measure of the propensity that each fish feeds (Gomes-Ferreira et al., 2005).

Numerical abundance $\left(A_{\mathrm{N}}, \%\right)$, based on the total number of prey in the sample, and frequency of occurrence $\left(F_{\mathrm{O}}, \%\right)$ excluding empty guts were calculated according to Hyslop (1980). The modification of Costello (1990) graphical representation was applied to assess the forage behavior and determine dominant prey types (Amundsen et al., 1996). The Amundsen modification (Amundsen et al., 1996) classifies prey selection by plotting prey-specific abundance $\left(P_{i}\right)$ against frequency of occurrence (Gomes-Ferreira et al., 2005). This graphical approach allows for determination of prey import- ance and feeding strategy of the predator. Rare prey are located in the lower left of the diagram and dominant prey are located in the upper right of the diagram. A concentration of points in the lower portion of the diagram suggests a generalized feeding strategy, whereas points in the upper portion of the diagram reflect a specialized feeding strategy.

Percentage overlap between the diets of mature male, mature female and immature inland silverside each month was calculated using the Renkonen overlap index (Krebs, 1989; Marshall and Elliot, 1997):

To determine if significant differences existed in prey items consumed between mature male, mature female, and immature inland silverside, a Kruskal-Wallis rank-sum test was applied to $A_{\mathrm{N}}$ and $F_{\mathrm{O}}$ of each prey item. When significant differences were found, a post hoc Mann-Whitney-Wilcoxon two-sample rank-sum test (Matlab v. 7.1) for group differences was used to locate pair-wise groups that differed (Day and Quinn, 1989).

\section{Results}

Food consumption

A total of 180 sexually mature males (31-95 mm, TL), 50 sexually mature females (61-107 mm, TL), and 320 (22$90 \mathrm{~mm}$, TL) immature inland silverside was analyzed. The feeding activity index varied among mature male, mature female, and immature M. beryllina (Table 1). Males had the least feeding activity index, whereas immature inland silverside had the greatest. There were significant differences in median stomach fullness $(\mathrm{P}<0.001)$. Median stomach fullness was significantly different between males and females $(\mathrm{P}=0.0244)$ and males and immature $(\mathrm{P}<0.001)$ inland silverside, but not significantly different between females and immature $(P=0.2719)$. Immature inland silverside had the greatest median stomach fullness, followed by adult females and then adult males.

The diet of mature male, mature female and immature inland silverside was dominated by copepods in both $A_{\mathrm{N}}$ and $F_{\mathrm{O}}$ (Table 2). There were significant differences in $A_{\mathrm{N}}$ of copepods between male and immature inland silverside $(\mathrm{P}<0.001)$. The $A_{\mathrm{N}}$ of Chydorus was significantly different between male and immature $(\mathrm{P}<0.001)$ and female and immature $(\mathrm{P}<0.001)$ inland silverside. The $A_{\mathrm{N}}$ of Daphnia significantly differed in male and immature $(\mathrm{P}<0.001)$ and female and immature $(\mathrm{P}=0.0292)$ inland silverside. There were significant differences in $F_{\mathrm{O}}$ of Chydorus, Daphnia, and Diptera. The $F_{\mathrm{O}}$ of Chydorus significantly differed between male and immature $(\mathrm{P}<0.001)$ as well as female and immature $(\mathrm{P}=0.006)$ inland silverside. There were significant differences in $F_{\mathrm{O}}$ of Daphnia in male and immature $(\mathrm{P}<0.001)$ and female and immature $(\mathrm{P}=0.006)$ inland

Table 1

Average feeding indices for mature male, mature female, and immature inland silverside (Menidia beryllina) in an inland water body (Lubbock County, TX, USA)

\begin{tabular}{lclc}
\hline & Male & Female & Immature \\
\hline $\begin{array}{l}\text { Sample size (n) } \\
\begin{array}{l}\text { Feeding activity } \\
\text { index (\%) }\end{array}\end{array}$ & 180 & 50 & 320 \\
$\begin{array}{l}\text { Median stomach } \\
\text { fullness (\%) }\end{array}$ & 82.78 & 90.00 & 92.19 \\
\hline
\end{tabular}


Table 2

Numerical abundances $\left(A_{\mathrm{N}}\right)$ and frequency of occurrences $\left(F_{\mathrm{O}}\right)$ for items found in guts of mature male, mature female and immature inland silverside (Menidia beryllina) in an inland water body (Lubbock County, TX, USA)

\begin{tabular}{lllllll}
\hline & \multicolumn{2}{l}{ Males } & \multicolumn{3}{c}{ Females } & Immature \\
\cline { 2 - 6 } Food items & $A_{\mathrm{N}}(\%)$ & $F_{\mathrm{O}}(\%)$ & $A_{\mathrm{N}}(\%)$ & $F_{\mathrm{O}}(\%)$ & $A_{\mathrm{N}}(\%)$ & $F_{\mathrm{O}}(\%)$ \\
\hline Copepods* & 51.29 & 91.95 & 62.46 & 100.00 & 66.47 & 94.74 \\
Bosmina $_{\text {Chydorus* }}$ & 16.42 & 80.46 & 10.49 & 67.74 & 18.01 & 78.95 \\
Daphnia* $_{\text {Diptera* }}$ & 7.98 & 45.98 & 6.76 & 51.61 & 1.68 & 20.30 \\
& 24.52 & 72.41 & 19.58 & 70.59 & 12.433 & 45.86 \\
\hline
\end{tabular}

*Statistical differences $(\mathrm{P}<0.05)$ between mature male, mature female and immature Menidia beryllina (Kruskal-Wallis test). silverside. Also, $F_{\mathrm{O}}$ of Diptera was significantly different between female and immature inland silverside $(\mathrm{P}=0.04)$.

The predominance of all prey in mature male, mature female and immature M. beryllina was located at the lower portion of the Costello plot (Fig. 2). By using the Costello graphing method, inland silverside should be considered generalists, with copepods as the predominant prey. There was no indication of prey specialization by mature male, mature female and immature inland silverside.

\section{Seasonal diet variation}

Percent stomach fullness significantly differed monthly for males $\left(\chi^{2}=12.72\right.$, d.f. $\left.=4, \mathrm{P}=0.0127\right)$, whereas percent stomach fullness did not significantly differ monthly for females and immature inland silverside $\left(\chi^{2}=2.78\right.$, d.f. $=4$, $\mathrm{P}=0.5972 ; \chi^{2}=4.886$, d.f. $=2, \mathrm{P}=0.0869$, respectively)

There was some variation in the $A_{\mathrm{N}}$ of several prey items (Fig. 3). Copepods were the predominant prey year-round for mature male, mature female, and immature. Ingestion of Bosmina and Daphnia by males increased with the length of the growing season. Ingestion of Daphnia by females during July substantially increased relative to earlier and later in the season. Ingestion of copepods in females also increased with the length of the growing season. In immature inland silverside, copepods were the predominant prey throughout the growing season, but there was a switch in secondary importance of Bosmina in July to Diptera in September.

\section{Resource overlap}

Considerable overlap $(>60 \%)$ in diet existed for most of the season between mature male, mature female and immature inland silverside. There was a remarkable shift in extent of overlap during July and August between mature male, mature female and immature inland silverside (Fig. 4). Female and immature inland silverside had the least degree of overlap $(45.18 \%)$ in July followed by male and female diets in August $(56.10 \%)$. The greatest overlap $(94.00 \%)$ occurred in September between males and immature inland silverside followed by males and females in May $(90.02 \%)$.

One hundred percent of individuals collected during May through June were mature adults. In July, only $27 \%$ of the inland silverside captured were mature adults and by September $11 \%$ of the inland silverside were mature.

\section{Discussion}

Huber and Bengtson (1999) described a rapid disappearance of sexually mature inland silverside during the summer and speculated that energetic demands placed on adults for rapid somatic and reproductive growth lead to early death, partic-
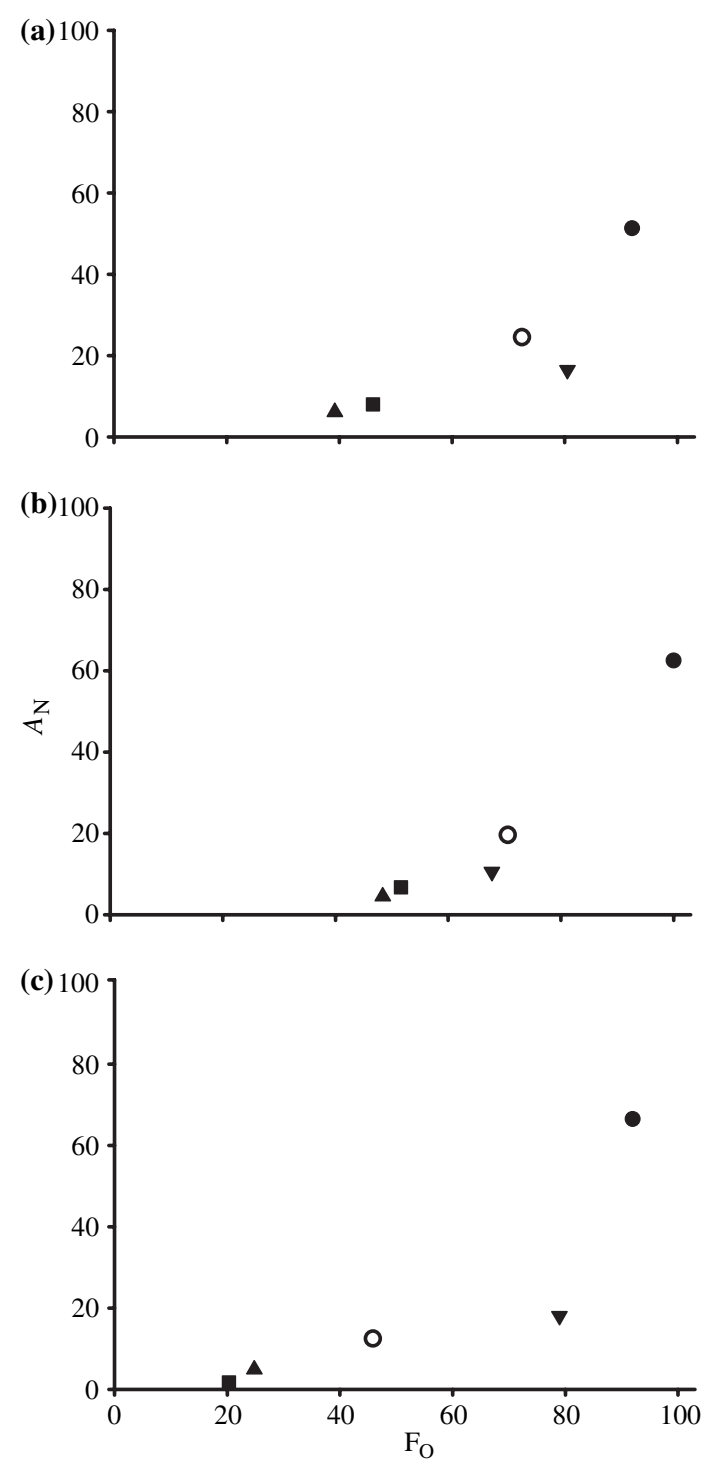

Fig. 2. Modified graphical representation [plots of prey-specific abundance $\left(A_{\mathrm{N}}\right)$ and frequency of occurrence $\left(F_{\mathrm{O}}\right)$; Costello, 1990] for diet $(\boldsymbol{\bullet}$, copepods; $\mathbf{\nabla}$, Bosmina; $\boldsymbol{\square}$, Chydorus; $\bigcirc$, Daphnia; $\boldsymbol{\Lambda}$, Diptera) of (a) mature male; (b) mature female; and (c) immature inland silverside (Menidia beryllina) in Buster Long Lake, Texas, USA

ularly in females. The 'metabolic burnout' by adults seems a likely explanation for the rapid disappearance of adults from the population, but it also provides a possible mechanism to sustain two periods of rapid growth in subsequent generations. Few adults are present to compete for food resources with immature $M$. beryllina in late summer and autumn, whereas few immature fish are present to compete for resources with 

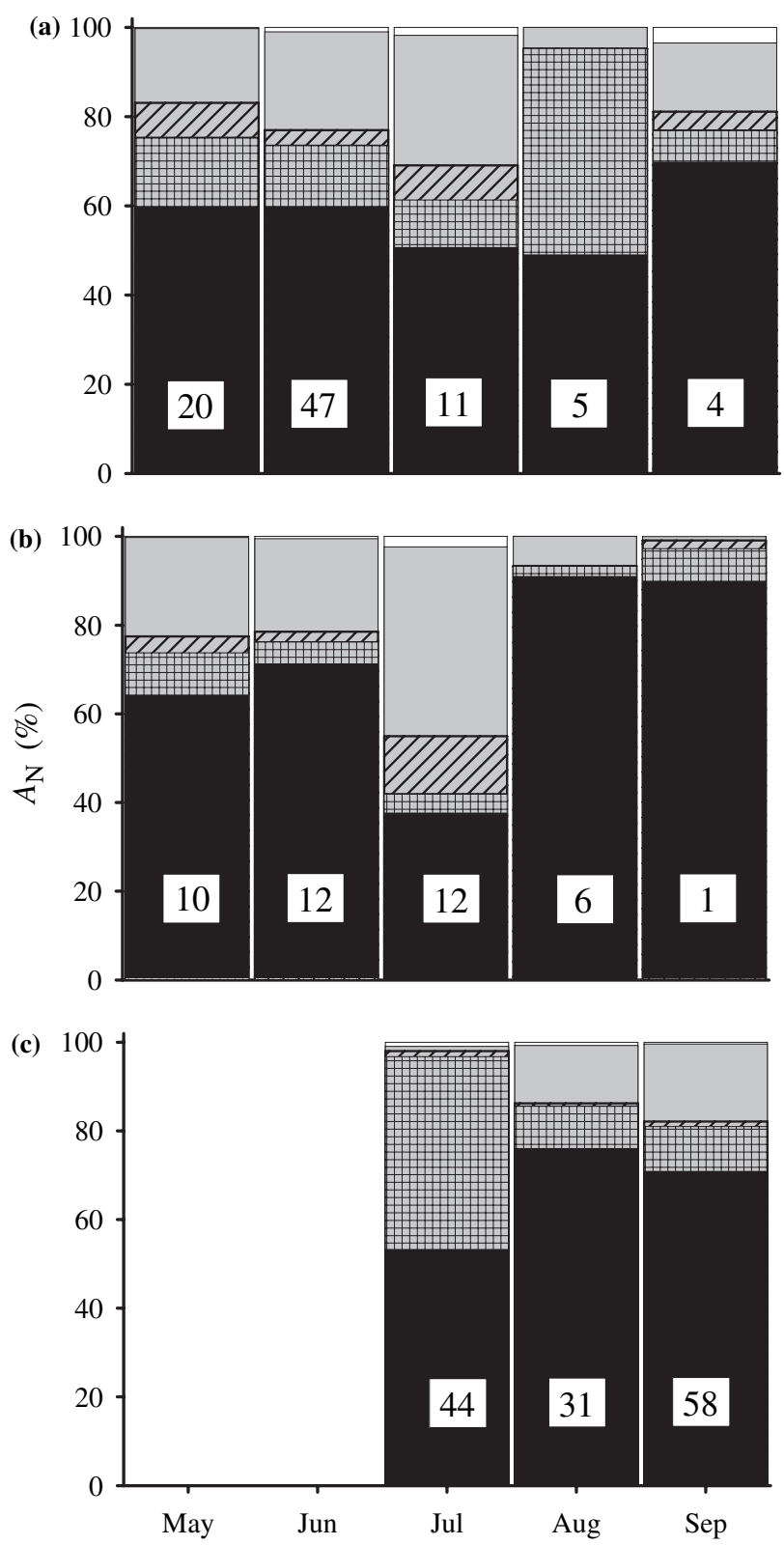

Fig. 3. Relative seasonal variation in numerical abundance of prey items for (a) mature male; (b) mature female; and (c) immature Menidia beryllina in Buster Long Lake, Texas, USA. Food items are: 口, copepods; 聿, Bosmina; 目, Chydorus; $\square$, Daphnia; and , Diptera. Number enclosed in each bar represents number of stomachs examined

adults in spring and early summer. The degree of resource overlap in this study was the greatest before and following winter. The two observed periods of growth rates (Huber and Bengtson, 1999) correspond to the dominance of immature and adult inland silverside in the population. During the first growth period, there was substantial food resource overlap but there was a low abundance of sexually mature adults that essentially minimized the per capita effect of intraspecific competition on immature inland silverside. During the second growth period no immature inland silverside were caught in samples, indicating little competition for resources between adult and immature $M$. beryllina. It is during this period when adults are maximizing energy allocation into somatic and reproductive growth. The life history patterns of inland silverside allow for a reduction in resource overlap during the two major growth phases by reducing the number of competing individuals, thus maximizing energy allocation at

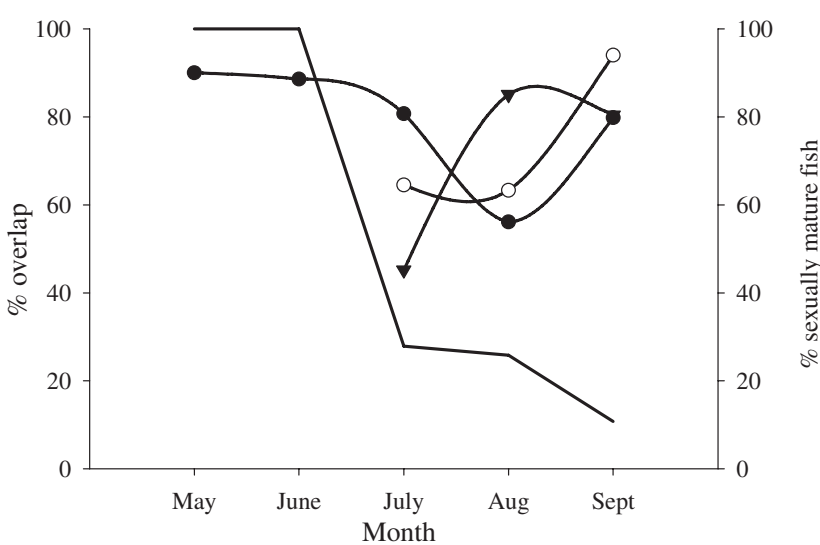

Fig. 4. Percent sexually mature fish and monthly dietary overlap between male and female $(\bullet)$, male and immature $(\bigcirc)$, and female to immature $(\boldsymbol{\nabla})$ inland silverside (Menidia beryllina) in Buster Long Lake, Texas, USA

each stage. Therefore, during summer (June and July) it would be expected that there would be mechanisms in place that would continue reduced intraspecific competition and maximization of energy allocation for adults and juveniles.

During summer, there was an observed divergence in resource overlap between mature male, mature female, and immature inland silverside. The adults, particularly females, were investing vast resources into reproduction and at the same time newly-emerged larvae began investing energy into somatic growth. Huber and Bengtson (1999) observed female inland silverside investing substantially more energy into liver and gonad weight than did males. Liver weight or hepatosomatic index (HSI) is an indicator of absolute energy reserves (Plante et al., 2005) that are potentially available for investment into reproduction. After male and female inland silverside livers reached peak weights in spring, the HSI for males declined thereafter, while HSI for females increased throughout the remainder of the season. This physiological information correlates with the resource partitioning observed in this study. The decline in male HSI and GSI after reaching a peak in early spring is an indication that males do not sustain large investments in reproduction throughout the season, whereas females increased investment throughout. Thus, female inland silverside must continually consume energy rich prey throughout the duration of the breeding season. The divergence in energy demands by male and female inland silverside in early summer provides an explanation for trends in feeding activity index and median percent stomach capacity. Male inland silverside fed on a broad range of prey types during July, the height of the breeding season, but had the lowest feeding index and least stomach fullness. Simultaneously, females had a large feeding index and percent stomach fullness, and consumed the largest of observed prey species (Daphnia and Diptera). This divergence in diets was likely necessary to minimize competition between males and females, in order to provide female inland silverside energy reserves necessary to maintain heightened reproduction. At the same time, immature inland silverside were beginning to hatch from eggs and initiating exogenous feeding, although because of gape limitation they feed predominately on smaller prey (DeVries et al., 1998). In July immature inland silverside (Fig. 4) predominately consumed copepods and Bosmina, the smallest of observed prey items. Prey selection by female and immature inland silverside, the two groups with greatest 
energy demand, are at two different extremes of prey size, hence minimizing competition of the same food resource during the period of heightened energy demand.

Life-history theory dictates that there are tradeoffs between energy allocation in maintenance and somatic and reproductive growth. Inland silverside is an opportunistic strategist, faced with intense somatic and reproductive pressure over a short period. To maximize individual growth among mature male, mature female and immature inland silverside, there are population-level demographic responses to energy acquisition. One method by which inland silverside accomplishes this is through temporal separation of juveniles and adults during the two growth phases, minimizing intraspecific competition and maximizing per capita energy allocation. The other method, resource partitioning, occurs when mature male, mature female and immature inland silverside are all present in the population. The two strategies employed by inland silverside at the population level likely maximize the individual energy allocation necessary to maintain this opportunistic life strategy. Although controversy still exists about whether population dynamics can be derived from features of individuals (Lomnicki, 1999), the authors have attempted to demonstrate that energy allocation at the individual level drives population dynamics in inland silverside, and likely other opportunistic strategists. There needs to be further effort to identify the role that individual energy allocation decisions drive population dynamics in organisms with different life history strategies.

\section{Acknowledgements}

This study was funded in part by the generosity of the Allensworth Endowment for undergraduate research and the Honors College of Texas Tech University. This manuscript was submitted in fulfillment of undergraduate research completed by CGH. The authors thank F. Martinez Jr, C. Palmer, and $\mathrm{R}$. Brown for their assistance in the field and laboratory. This is manuscript number T-9-1101 of the College of Agricultural Sciences and Natural Resources, Texas Tech University.

\section{References}

Amundsen, P. A.; Gabler, H. M.; Staldvik, F. J., 1996: A new approach to graphical analysis of feeding strategy from stomach contents data - modification of the Costello (1990) method. J. Fish Biol. 48, 607-614.
Bengtson, D. A., 1982: Resource partitioning by Menidia menidia (L.) and Menidia beryllina (Cope) in two Rhode Island estuaries. PhD dissertation, University of Rhode Island, Kingston, RI, USA.

Bengtson, D. A., 1984: Resource partitioning by Menidia menidia and Menidia beryllina (Osteichthyes: Atherinidae). Mar. Ecol. Prog. Ser. 18, 21-30.

Bengtson, D. A., 1985: Laboratory experiments on mechanisms of competition and resource partitioning between Menidia menidia (L.) and Menidia beryllina (Cope) (Osteichthyes: Atherinidae). J. Exp. Mar. Biol. Ecol. 92, 1-18.

Costello, M. J., 1990: Predator feeding strategy and prey importance: a new graphical analysis. J. Fish Biol. 36, 261-263.

Day, R. W.; Quinn, G. P., 1989: Comparisons of treatments after an analysis of variance in ecology. Ecol. Monogr. 59, 433-463.

DeVries, D. R.; Bremigan, M. T.; Stein, R. A., 1998: Prey selection by larval fishes as influenced by available zooplankton and gape limitation. Trans. Am. Fish. Soc. 127, 1040-1050.

Gomes-Ferreira, A.; Ribeiro, F.; Moreira da Costa, L.; Cowx, I. G.; Collares-Pereira, M. J., 2005: Variability in diet and foraging behaviour between sexes and ploidy forms of the hybridogenetic Squalius alburnoides complex (Cyprinidae) in the Guadiana River basin, Portugal. J. Fish Biol. 66, 444-467.

Huber, M.; Bengtson, D. A., 1999: Interspecific differences in growth and reproductive tissues during the breeding season in Menidia menidia and M. beryllina. J. Fish Biol. 55, 274-287.

Knight, R. L.; Margraf, F. J., 1982: Estimating stomach fullness in fishes. N. Am. J. Fish. Manage. 2, 413-414.

Krebs, C. J., 1989: Ecological methodology. Harper Collins, New York.

Lomnicki, A., 1999: Individual-based models and the individual-based approach to population ecology. Ecol. Modell. 115, 191-198.

Marshall, S.; Elliot, M., 1997: A comparison of univariate and multivariate numerical and graphical techniques for determining inter- and intraspecific feeding relationships in estuarine fish. J. Fish Biol. 51, 526-545.

Plante, S.; Audet, C.; Lambert, Y.; De la Noue, J., 2005: Alternative methods for measuring energy content in winter flounder. N. Am. J. Fish. Manage. 25, 1-6.

Schramm, H. L., Jr; Black, R. C.; Molhage, T. R.; Ramsey, R. H.; Smith, L. M.; Urban, L. V., 1992: Fisheries, waterfowl, and recreation in an urban stormwater management system. In: Solutions to non-point source pollution. R. Jensen (Ed.). Texas Water Resource Institute, College Station, TX, pp. 65-77.

Shavlik, C. E., 2000: An assessment of largemouth bass and panfish population dynamics in west Texas ponds. Master's thesis, Texas Tech University, Lubbock, TX.

Smith, L. M., 2003: Playas of the Great Plains. University of Texas Press, Austin, TX.

Stoeckel, J. N., 1984: The biology of the inland silverside (Menidia beryllina) in a relation to its potential as a forage fish in southern Illinois. Master's thesis. University of Southern Illinois, Carbondale, IL, USA.

Author's address: C. J. Chizinski, Wildlife and Fisheries Management Institute, Mail Stop 2125, Texas Tech University, Lubbock, TX 79409, USA.

E-mail: chris.chizinski@ttu.edu 